\title{
PENGGUNAAN MODUL MATRIKS UNTUK MENINGKATKAN HASIL BELAJAR MATEMATIKA PESERTA DIDIK KELAS XI SMK
}

\author{
MUSDALIFAH \\ SMK Muhammadiyah Watansoppeng \\ e-mail: musdalifahsmkmuhsoppeng@gmail.com
}

\begin{abstract}
ABSTRAK
Penelitian ini adalah penelitian tindakan kelas (Classroom Action Reseach) yang dilaksanakan di SMK Muhammadiyah Watansoppeng dan bertujuan untuk meningkatkan hasil belajar matematika melalui penggunaan modul matriks pada peserta didik kelas XI SMK Muhammadiyah Watansoppeng. Subjek penelitian ini adalah siswa kelas XI SMK Muhammadiyah Watansoppeng pada tahun pelajaran 2021/2022 sebanyak 15 siswa. Teknik pengumpulan data yang digunakan adalah tes hasil belajar dan observasi. Data yang terkumpul dianalisis dengan menggunakan analisis deskriptif dengan menggunakan analisis secara kuantitatif dan kualitatif. Hasil analisis menunjukkan adanya peningkatan hasil belajar matematika. Hasil analisis kuantitatif menunjukkan bahwa skor rata-rata penguasaan peserta didik pada siklus I sebesar 70,53 berada dalam kategori tinggi dengan persentase ketuntasan mencapai $60 \%$, hal ini menunjukkan bahwa peserta didik belum mencapai ketuntasan kelasikal. Dan skor rata-rata penguasaan peserta didik pada siksus II sebesar 78,27 berada dalam kategori tinggi dengan persentase ketuntasan mencapai $87 \%$, hal ini menunjukkan bahwa peserta didik sudah mencapai ketuntasan kelasikal. Hasil analisis kualitatif berdasarkan observasi menunjukkan peningkatan aktivitas peserta didik yang sesuai dengan pembelajaran yakni meningkatnya peserta didik hadir dalam proses belajar, yang aktif bertanya tentang materi yang belum jelas pada modul matriks, yang bertukar pendapat dengan peserta didik lain dalam menyelesaikan permasalahan pada modul matriks, yang aktif memberikan tanggapan terhadap pertanyaan teman yang lain, yang mengerjakan soal latihan dalam modul yang diberikan oleh guru, dan terjadi penurunan aktivitas peserta didik yang tidak sesuai dengan pembelajaran. Berdasarkan hasil analisis tersebut, nampak adanya perubahan bahwa penggunaan modul cukup efektif untuk meningkatkan hasil belajar matematika pada peserta didik kelas XI SMK Muhammadiyah Watansoppeng pada materi matriks.
\end{abstract}

Kata Kunci: modul matriks, hasil belajar matematika

\section{ABSTRACT}

This research is a class action research (Classroom Action Research) which was carried out at SMK Muhammadiyah Watansoppeng and aims to improve mathematics learning outcomes through the use of matrix modules in class XI students of SMK Muhammadiyah Watansoppeng. The subjects of this study were 15 students of class XI SMK Muhammadiyah Watansoppeng in the 2021/2022 academic year. Data collection techniques used are learning outcomes tests and observations. The data collected were analyzed using descriptive analysis using quantitative and qualitative analysis. The results of the analysis showed an increase in mathematics learning outcomes. The results of quantitative analysis show that the average score of mastery of students in the first cycle of 70.53 is in the high category with the percentage of completeness reaching $60 \%$, this indicates that students have not achieved classical mastery. And the average score of mastery of students in cycle II of 78.27 is in the high category with the percentage of completeness reaching $87 \%$, this shows that students have achieved classical mastery. The results of qualitative analysis based on observations showed an increase in student activity in accordance with learning, namely the increase in students attending the learning process, who actively asked questions about material that was not clear in the matrix module, who exchanged opinions with other students in solving problems in the matrix module, which actively respond to other friends' questions, who are working on practice questions in the module given by the teacher, and there is a decrease in student activity that is not in accordance with learning. Based 
on the results of the analysis, it appears that there is a change that the use of the module is quite effective in improving mathematics learning outcomes in class XI students of SMK Muhammadiyah Watansoppeng on matrix material.

Keywords: matrix module, mathematics learning outcomes

\section{PENDAHULUAN}

Salah satu materi pendidikan yang sangat berpengaruh dalam kehidupan adalah matematika yang dapat menjadi sarana berpikir logis, analitis, dan sistematis dalam dunia pendidikan. Menurut Soedjadi (2020) matematika merupakan ilmu yang mempunyai karakteristik tertentu jika dibandingkan dengan disiplin ilmu lainnya. Salah satu karakteristik matematika adalah memiliki objek kajian abstrak. Objek dasar matematika terdiri dari fakta, konsep, operasi, dan prinsip. Oleh karena itu, belajar matematika harus dilakukan secara bertahap, berurutan, dan sistematis serta didasarkan pada pengalaman belajar yang lalu. Para peserta didik di berbagai jenjang pendidikan mutlak dituntut untuk menguasai pelajaran matematika. Dengan mempelajari matematika, peserta didik diharapkan dapat memiliki prestasi yang memuaskan dan mampu memecahkan segala persoalan yang dihadapi baik masalah yang berkaitan dengan pelajaran matematika itu sendiri maupun berkaitan dengan kehidupan seharihari.

Namun dalam kenyataannya, matematika merupakan pelajaran yang kurang disenangi oleh peserta didik, karena dianggap memiliki rumus-rumus yang sulit dimengerti. Salah satu alternatif yang dapat dilakukan untuk mengatasi masalah tersebut adalah dengan menggunakan media pembelajaran yang tepat dengan kondisi psikologi peserta didik, sehingga dapat membantu peserta didik untuk menggunakan waktunya dengan sefisien mungkin, sehingga peserta didik mudah memahami pelajaran matematika. Dengan demikian maka hasil belajar peserta didik dapat meningkat sesuai yang diharapkan.

Pada dasarnya media pembelajaran merupakan alat bantú visual dalam kegiatan pembelajaran, yaitu berupa sarana yang dapat memberikan pengalaman visual kepada peserta didik antara lain untuk mendorong motivasi belajar, memperjelas dan mempermudah konsep yang kompleks dan abstrak menjadi lebih sederhana, konkrit, serta mudah dipahami. Menurut Miarso dalam Musfikon (2012: 32) media dapat berfungsi untuk mempertinggi daya serap belajar siswa terhadap materi pembelajaran. Hal ini didukung oleh Arsyad (2006: 15) yang mengemukakan bahwa pemakaian media pembelajaran dalam proses belajar mengajar dapat membangkitkan keinginan dan minat baru, membangkitkan motivasi dan merangsang kegiatan belajar, dan bahkan membawa pengaruh-pengaruh psikologi terhadap peserta didik. Penggunaan media pembelajaran pada tahap orientasi pembelajaran akan sangat membantu keefektifan proses pembelajaran dan penyampaian pesan dan isi pembelajaran pada saat itu.

Salah satu media yang digunakan adalah penggunaan modul dalam pembelajaran matematika khususnya pada materi matriks. Modul merupakan suatu cara pengorganisasian materi pelajaran yang memperhatikan fungsi pendidikan. Menurut Winkel (2009: 472) modul pembelajaran adalah program studi belajar mengajar. Modul pembelajaran adalah satuan program terkecil yang dapat dipelajari secara mandiri. Hal ini sejalan dengan pendapat Wijaya (1998: 128) yang mengatakan bahwa modul pembelajaran merupakan satuan kegiatan belajar atau paket program yang terencana sekaligus sistematis. Umumnya modul dibuat dengan tujuan agar peserta didik dapat mencapai proses atau tujuan belajar tertentu. Sedangkan menurut Vembriarto (1975: 20) modul pembelajaran merupakan paket pembelajaran yang memiliki konsep bahan pembelajaran. Dengan demikian, dapat disimpulkan bahwa modul pembelajaran merupakan paket atau program pembelajaran yang tersusun secara terencanaa dan sistematis yang dapat dipelajari peserta didik secara mandiri untuk mencapai proses atau tujuan belajar tertentu.

Penggunaan modul pembelajaran diharapkan mampu membawa peserta didik pada kompetensi yang diharapkan. Modul dapat membantu guru dalam mewujudkan pembelajaran yang berkualitas. Penerapan modul dapat mengkondisikan kegiatan pembelajaran lebih 
terencana dengan baik, mandiri, tuntas, dan dengan hasil (output) yang jelas. Strategi pengorganisasian materi pelajaran pada modul mengandung sequencing yang mengacu pada pembuatan urutan penyajian materi pembelajaran, synthesizing yang mengacu pada upaya untuk menunjukkan kepada peserta didik keterkaitan fakta, konsep, prosedur dan prinsip yang terkandung dalam materi pembelajaran. Untuk merancang modul yang baik dan menarik, terdapat lima karakteristik modul yaitu: (1) self instruktional, (2) self contained, (3) stand alone (berdiri sendiri), (4) adaptive, dan (5) user friendly.

Berikut ini adalah beberapa hasil penelitian terdahulu yang relevan dengan penelitian ini, yaitu (1) hasil penelitian Ahmadi dan Rokhman (2018) menunjukkan bahwa modul efektif dalam meningkatkan hasil belajar mahasiswa, (2) hasil penelitian Ramadhani dan Amudi (2020) menunjukkan bahwa pemberian modul matematika dasar kontekstual materi bilangan efektif meningkatkan hasil belajar mahasiswa dengan kategori peningkatan "sedang", (3) hasil penelitian Mapilindo, Rahmayanti, dan Gulyanto (2021) menunjukkan bahwa pemberian modul matematika dapat meningkatkan hasil belajar siswa dengan kategori peningkatan "sedang".

Berdasarkan data dari beberapa guru matematika di SMK Muhammadiyah Watansoppeng, masih banyak peserta didik yang memiliki hasil belajar matematika yang belum mencapai nilai KKM. Pernyataan ini dibuktikan dari nilai rata-rata hasil belajar matematika peserta didik kelas X semester genap tahun 2020/2021 yaitu 67,20 masih dibawah nilai KKM yang ditetapkan sekolah yaitu 70 dari skor ideal. Hal ini disebabkan peserta didik belum tertarik mengikuti proses pembelajaran dan merasa bosan dikarenakan penyajian materi matematika masih menggunakan media konvensional. Oleh karena itu penulis bermaksud melakukan penelitian dengan judul "Penggunaan modul matriks untuk meningkatkan hasil belajar matematika pada peserta didik kelas XI SMK".

\section{METODE PENELITIAN}

Penelitian ini merupakan penelitian tindakan kelas (classroom action research) yang pelaksanaannya terdiri dari empat tahap yaitu: perencanaan, pelaksanaan tindakan, observasi dan refleksi. Subjek penelitian ini adalah peserta didik kelas XI SMK Muhammadiyah Watansoppeng pada semester ganjil tahun pelajaran 2021/2022 yang berjumlah 15 orang, terdiri dari 10 laki-laki dan 5 perempuan. Adapun instrumen penelitian yang akan digunakan dalam penelitian ini adalah tes hasil belajar dan lembar observasi. Data yang diperoleh dari instrumen tersebut adalah tes hasil belajar dan hasil observasi aktivitas peserta didik. Pada penelitian ini, tes hasil belajar dimaksudkan untuk mengukur tingkat keberhasilan peserta didik terhadap materi pelajaran setelah diterapkan penggunaan modul matematika pada materi matriks. Sedangkan lembar observasi dalam penelitian ini dimaksudkan untuk melihat aktivitas yang dilakukan peserta didik selama proses pembelajaran berlangsung dengan menggunakan modul matriks. Data yang terkumpul dianalisis dengan analisis kuantitatif dan kualitatif. Data hasil belajar dianalisis secara kuantitatif dengan menggunakan statistika deskriptif untuk mendeskripsikan hasil belajar dalam bentuk nilai tertinggi, terendah, dan standar deviasi. Data mengenai observasi aktivitas peserta didik dianalisis secara kualitatif.

\section{HASIL DAN PEMBAHASAN}

\section{Hasil}

Pada siklus I dilakukan tes hasil belajar yang berbentuk soal uraian. Pelaksanaan tes tesebut dilakukan setelah selesai penyajian materi matriks dengan menggunakan modul. Data yang diperoleh dari tes pada akhir siklus I untuk menggambarkan tingkat pemahaman peserta didik melalui penggunaan modul pembelajaran pada materi matriks. Adapun penyajiannya dapat dilihat pada tabel 1 berikut: 
Tabel 1 Statistik Skor Hasil Belajar Matematika Siswa pada Siklus I

\begin{tabular}{|c|c|}
\hline Statistik & Nilai Statistik Siklus I \\
\hline Subjek & 15 \\
Skor tertinggi & 81 \\
Skor terendah & 52 \\
Rentang skor & 29 \\
Skor rata-rata & 70,53 \\
Standar deviasi & 10,79 \\
Persentase Tuntas & $60 \%$ \\
Persentase Tidak Tuntas & $40 \%$ \\
& \\
\hline
\end{tabular}

Berdasarkan tabel tersebut diatas menunjukkan bahwa skor rata-rata hasil belajar matematika peserta didik setelah penggunaan modul matriks adalah 70,53 dengan standar deviasi 10,79, skor tetinggi yang diperoleh peserta didik pada siklus I adalah 81, sedangkan skor terendah adalah 52 .

Jika hasil belajar matematika peserta didik pada siklus I dianalisis dengan persentase ketuntasan belajar matematika menunjukkan persentase ketuntasan secara kelasikal pada siklus I yaitu sebesar 60\% (9 dari 15 peserta didik) berada pada kategori tuntas dan $40 \%$ (6 dari 15 peserta didik) berada pada kategori tidak tuntas, ini berarti belum tercapai ketuntasan secara kelasikal.

Apabila hasil belajar matematika siswa pada Siklus I dikelompokkan dalam lima kategori menurut Departemen Pendidikan Nasional, maka diperoleh distribusi frekuensi dan persentase hasil belajar matematika siswa pada Tabel 2 berikut ini:

Tabel 2. Distribusi Frekuensi dan Persentase Hasil Belajar Matematika Siswa pada Siklus I

\begin{tabular}{|c|c|c|c|c|}
\hline $\begin{array}{c}\text { Tingkat } \\
\text { Penguasaan }\end{array}$ & Skor & Kategori & Frekuensi & Persentase \\
\hline $85 \%-100 \%$ & $85-100$ & Sangat tinggi & 0 & $0 \%$ \\
\hline $65 \%-84 \%$ & $65-84$ & Tinggi & 9 & $60,00 \%$ \\
\hline $55 \%-64 \%$ & $55-64$ & Sedang & 4 & $26,67 \%$ \\
\hline $35 \%-54 \%$ & $35-54$ & Rendah & 2 & $13,33 \%$ \\
\hline $0 \%-34 \%$ & $0-34$ & Sangat rendah & 0 & $0 \%$ \\
\hline \multicolumn{3}{|c|}{ Jumlah } & 15 & $100 \%$ \\
\hline
\end{tabular}

Berdasarkan tabel diatas menunjukkan bahwa 9 peserta didik atau $60 \%$ berada pada kategori tinggi, 4 peserta didik atau 26,67\% berada pada kategori sedang, 2 peserta didik atau $13,33 \%$ berada pada kategori rendah dan tidak ada peserta didik yang berada pada kategori sangat tinggi dan sangat rendah. Maka dapat dikemukakan bahwa skor rata-rata hasil belajar matematika setelah penggunaan modul pembelajaran materi matriks pada siklus I yaitu 70,53 berada dalam kategori tinggi.

Pada siklus II dilakukan tes hasil belajar yang berbentuk soal uraian. Pelaksanaan tes tersebut dilakukan setelah selesai penyajian materi matriks dengan menggunakan modul. Data yang diperoleh dari tes pada akhir siklus II untuk menggambarkan tingkat pemahaman peserta didik melalui penggunaan modul pembelajaran pada materi matriks. Adapun penyajiannya dapat dilihat pada tabel 3 berikut: 


\section{Tabel 3 Statistik Skor Hasil Belajar Matematika Siswa pada Siklus II}

\begin{tabular}{|c|c|}
\hline Statistik & Nilai Statistik \\
\hline Subjek & 15 \\
Skor tertinggi & 85 \\
Skor terendah & 64 \\
Rentang skor & 21 \\
Skor rata-rata & 78,27 \\
Standar deviasi & 6,79 \\
Persentase Tuntas & $87 \%$ \\
Persentase Tuntas & $13 \%$ \\
& \\
\hline
\end{tabular}

Berdasarkan tabel diatas menunjukkan bahwa skor rata-rata hasil belajar matematika peserta didik setelah penggunaan modul pembelajaran adalah 78,27 dengan standar deviasi 6,79 , skor tertinggi yang diperoleh peserta didik pada siklus II adalah 85, sedangkan skor terendah adalah 64 .

Jika hasil belajar matematika peserta didik pada siklus II dianalisis dengan ketuntasan belajar matematika peserta didik menunjukkan bahwa persentase ketuntasan secara kelasikal pada siklus II yaitu sebesar 87\% (13 dari 15 peserta didik) berada pada kategori tuntas dan 13\% ( 2 dari 15 peserta didik) berada pada kategori tidak tuntas, sehingga dapat disimpulkan bahwa pada siklus II hasil belajar matematika peserta didik mencapai ketuntasan kelasikal.

Apabila hasil belajar matematika siswa pada Siklus II dikelompokkan dalam lima kategori menurut Departemen Pendidikan Nasional, maka diperoleh distribusi frekuensi dan persentase hasil belajar matematika siswa pada Tabel 4 berikut ini:

\section{Tabel 4. Distribusi Frekuensi dan Persentase Hasil Belajar Matematika Siswa pada}

\section{Siklus II}

\begin{tabular}{|c|c|c|c|c|}
\hline $\begin{array}{c}\text { Tingkat } \\
\text { Penguasaan }\end{array}$ & Skor & Kategori & Frekuensi & Persentase \\
\hline $85 \%-100 \%$ & $85-100$ & Sangat tinggi & 0 & $0 \%$ \\
\hline $65 \%-84 \%$ & $65-84$ & Tinggi & 2 & $13,33 \%$ \\
\hline $55 \%-64 \%$ & $55-64$ & Sedang & 11 & $73,34 \%$ \\
\hline $35 \%-54 \%$ & $35-54$ & Rendah & 2 & $13,33 \%$ \\
\hline $0 \%-34 \%$ & $0-34$ & Sangat rendah & 0 & $0 \%$ \\
\hline \multicolumn{3}{|c|}{ Jumlah } & 15 & $100 \%$ \\
\hline
\end{tabular}

Berdasarkan tabel diatas menunjukkan bahwa 2 siswa atau 13,33\% berada pada kategori sangat tinggi, 11 peserta didik atau 73,34\% berada pada kategori tinggi, 2 peserta didik atau $13,33 \%$ berada pada kategori sedang, dan tidak ada lagi peserta didik yang berada pada kategori rendah dan sangat rendah. Hal ini menunjukkan bahwa terjadi peningkatan hasil belajar matematika peserta didik dibandingkan pada siklus I. Melihat skor rata-rata hasil belajar matematika peserta didik setelah penggunaan modul pembelajaran pada siklus II yaitu 78,27, maka hasil belajar matematika pada siklus II berada pada kategori tinggi.

Skor rata-rata hasil belajar matematika peserta didik setelah penggunaan modul pada siklus I sebesar 70,53 meningkat menjadi 78,27 pada siklus II. Persentase ketuntasan belajar juga meningkat dari siklus I sebesar $60 \%$ meningkat menjadi $87 \%$ pada siklus II.

Jenis aktivitas peserta didik yang diamati berupa aktivitas yang sesuai dengan pembelajaran dan aktivitas yang tidak sesuai dengan pembelajaran. Adapun jenis aktivitas yang sesuai dengan pembelajaran yaitu: (1) Peserta didik yang hadir dalam proses belajar mengajar; (2) Peserta didik yang aktif bertanya tentang materi yang belum jelas pada modul matriks; (3) 
Peserta didik yang bertukar pendapat dengan peserta didik lain dalam menyelesaikan permasalahan pada modul matriks; (4) Peserta didik yang aktif memberikan tanggapan terhadap pertanyaan teman; (5) Peserta didik yang aktif mengerjakan soal latihan yang diberikan oleh guru; (6) Peserta didik yang melakukan tindakan yang tidak sesuai dengan pembelajaran.

Untuk perbandingan persentase aktivitas peserta didik dari siklus I ke siklus II dapat dilihat pada diagram 1. berikut:

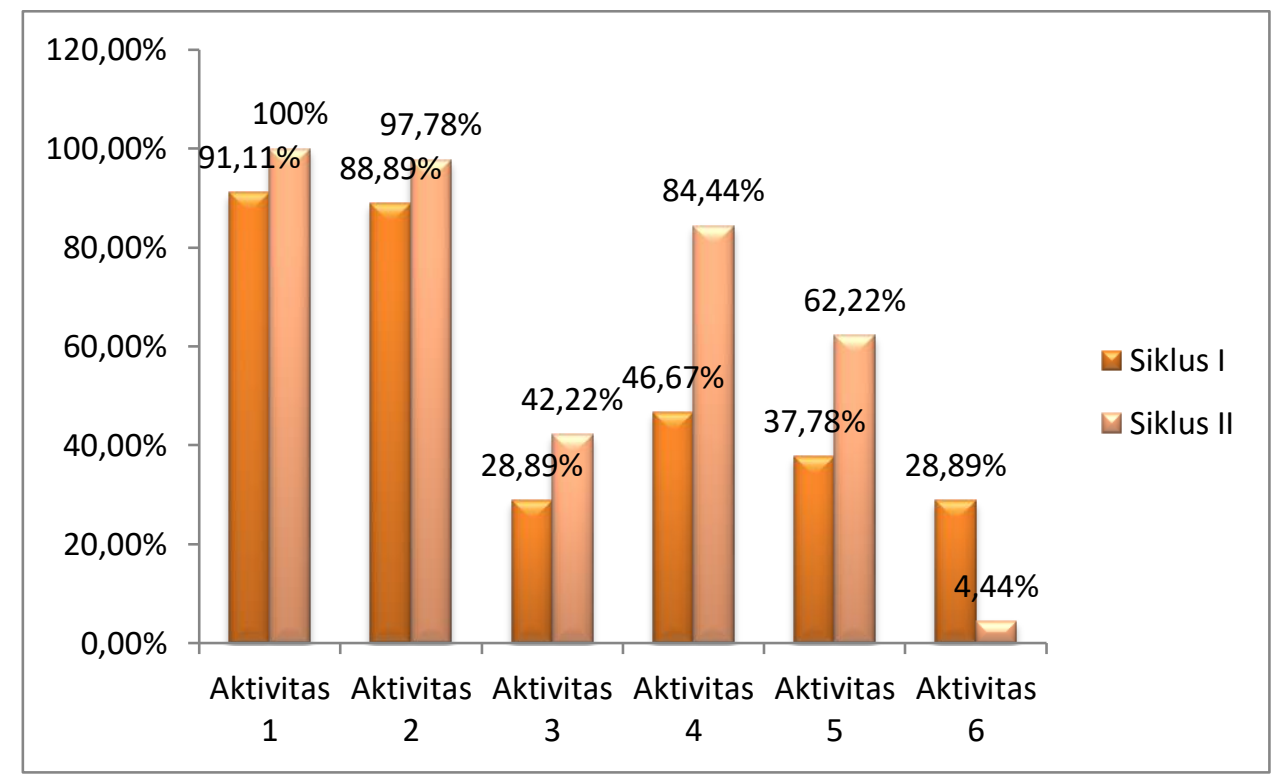

\section{Gambar 1. Diagram Perbandingan Persentase Aktivitas Peserta Didik Siklus I dan Siklus II}

\section{Pembahasan}

Penggunaan modul pembelajaran mampu membawa peserta didik pada kompetensi yang diharapkan. Modul dapat membantu guru dalam mewujudkan pembelajaran yang berkualitas. Penerapan modul dapat mengkondisikan kegiatan pembelajaran lebih terencana dengan baik, mandiri, tuntas, dan dengan hasil (output) yang jelas.

Hasil penelitian ini akan memberikan gambaran tentang tes hasil belajar matematika pada materi matriks dan aktivitas peserta didik selama pembelajaran berlangsung setelah diterapkan penggunaan modul pada peserta didik kelas XI SMK Muhammadiyah Watansoppeng.

Setelah melihat hasil analisis data, dapat diketahui bahwa hasil belajar matematika pada materi matriks dan persentase aktivitas peserta didik setelah diberikan pelajaran dengan penggunaan modul ternyata mengalami peningkatan. Hal ini dapat kita lihat pada skor rata-rata pada siklus I dan siklus II. Hal ini juga dapat dilihat dari ketuntasan belajar peserta didik, yaitu 13 peserta didik atau 87\% mencapai kriteria ketuntasan belajar sehingga sesuai dengan indikator keberhasilan pada penelitian ini yaitu tercapainya $85 \%$ peserta didik yang tuntas belajar sehingga telah tercapai ketuntasan secara kelasikal.

Adapun yang perlu ditingkatkan dari siklus I, diantaranya bagaimana cara agar peserta didik dapat lebih aktif dalam melakukan aktivitas yang sesuai dengan pembelajaran, serta bagaimana meminimalisir peserta didik yang melakukan aktivitas yang tidak sesuai dengan pembelajaran, dalam hal ini peserta didik yang tidak memperhatikan materi yang disajikan guru, peserta didik yang keluar masuk kelas, dan tindakan-tindakan yang mengganggu proses pembelajaran. Upaya yang dilakukan guru untuk mengaktifkan peserta didik dalam pembelajaran adalah melatih peserta didik untuk aktif dalam memperhatikan materi pelajaran, bertanya tentang materi pelajaran, memberikan tanggapan terhadap pertanyaan yang diajukan teman yang lain, dan mengerjakan soal latihan yang diberikan guru setelah pemberian modul. 
Siklus II dilaksanakan pada pertemuan kelima sampai kedelapan termasuk pemberian tes pada akhir siklus II. Pelaksanaan pembelajaran pada siklus ini sudah lebih baik jika dibandingkan dengan siklus I, ditinjau dari aktivitas peserta didik yang sesuai dengan pembelajaran menunjukkan adanya peningkatan dari siklus I ke siklus II. Di samping itu, aktivitas yang tidak sesuai dengan pembelajaran peserta didik dari siklus I ke siklus II mengalami penurunan. Dengan demikian dapat dikatakan bahwa penggunaan modul dapat meningkatkan aktivitas peserta didik selama pembelajaran berlangsung.

Penggunaan modul dapat menjadikan hasil belajar peserta didik meningkat, hal ini sesuai dengan fungsi penggunaan modul dalam proses pembelajaran yaitu meningkatkan kemampuan peserta didik untuk belajar sendiri tanpa tergantung kepada kehadiran guru. Modul merupakan bahan ajar yang dirancang secara sistematis berdasarkan kurikulum tertentu serta memungkinkan dipelajari secara mandiri. Penggunaan modul tidak terbatas hanya untuk pembelajaran di kelas, tetapi dapat digunakan secara mandiri dimana dan kapan saja. Materimateri pembelajaran disajikan secara lengkap dan terurut sehingga memudahkan peserta didik untuk mempelajarinya. Dengan modul peserta didik terlibat aktif dalam proses pembelajaran. Menurut Hamalik (2001: 172) pengajaran yang efektif adalah pengajaran yang memberikan kesempatan kepada peserta didik untuk melakukan aktivitas sendiri. Dengan demikian peserta didik dapat mengembangkan pemahaman sendiri dan berpikir kritis dalam menyelesaikan masalah yang terdapat dalam modul tersebut.

Adapun kelebihan belajar menggunakan modul menurut Tjipto (1991: 72) yaitu (1) meningkatkan motivasi peserta didik, (2) setelah pembelajaran selesai, guru mengetahui mana peserta didik yang berhasil dan mana yang tidak berhasil, (3) peserta didik mencapai hasil yang sesuai dengan kemampuannya dalam mengerjakan modul, (4) beban belajar terbagi lebih merata sepanjang semester, (dan (5) pendidikan lebih berdaya guna.

Berikut ini adalah beberapa hasil penelitian terdahulu yang relevan dengan penelitian ini, yaitu (1) hasil penelitian Ahmadi dan Rokhman (2018) menunjukkan bahwa modul efektif dalam meningkatkan hasil belajar mahasiswa, (2) hasil penelitian Ramadhani dan Amudi (2020) menunjukkan bahwa pemberian modul matematika dasar kontekstual materi bilangan efektif meningkatkan hasil belajar mahasiswa dengan kategori peningkatan "sedang", (3) hasil penelitian Mapilindo, Rahmayanti, dan Gulyanto (2021) menunjukkan bahwa pemberian modul matematika dapat meningkatkan hasil belajar siswa dengan kategori peningkatan "sedang".

\section{KESIMPULAN}

Berdasarkan analisis data dan pembahasan dapat disimpulkan bahwa hasil belajar matematika dapat ditingkatkan melalui penggunaan modul pembelajaran materi matriks pada siswa kelas XI SMK Muhammadiyah Watansoppeng pada semester ganjil, hal ini dapat dilihat dari:

a. Meningkatnya rata-rata hasil belajar matematika siswa 70,53 pada siklus I menjadi 78,27 pada siklus II.

b. Meningkatnya persentase siswa yang tuntas belajar yaitu $60 \%$ pada siklus I menjadi $87 \%$ pada siklus II.

c. Terjadinya peningkatan aktivitas siswa dalam proses belajar sesuai dengan hasil observasi yang dilakukan selama penelitian.

Berdasarkan hasil penelitian tindakan yang dilakukan selama dua siklus, maka dalam upaya peningkatan mutu pendidikan diajukan beberapa saran, antara lain:

a. Diharapkan kepada guru khususnya guru matematika agar menerapkan penggunaan modul pembelajaran materi matriks sejak dini untuk meningkatkan kemampuan siswa dalam menyelesaikan masalah-masalah pada materi matriks dan hasil belajar matematika pada umumnya.

b. Sebagai tindak lanjut penerapan, pada saat proses pembelajaran diharapkan guru untuk lebih mengawasi dan mengontrol siswa dalam memperhatikan materi pelajaran yang disajikan dalam modul. 
c. Diharapkan pula kepada guru bidang studi yang lain agar mampu mengembangkan dan menerapkan penggunaan modul dalam upaya peningkatan hasil belajar siswa.

d. Diharapkan pada pihak sekolah agar memaksimalkan sarana dan prasarana misalnya media pembelajaran matematika yang dapat membantu dalam proses pembelajaran.

\section{DAFTAR PUSTAKA}

Ahmadi. Rokhman, S, M. (2018). Efektivitas Modul Program Linear Dalam Meningkatkan Prestasi Belajar Matematika. TEOREMA: Jurnal Teori dan Riset Matematika. Volume 2 Nomor 2. http://dx.doi.org/10.25157/teorema.v2i2.1076

Arsyad. (2006). Media Pembelajaran. Jakarta : Raja Grafindo Persada.

Hamalik, Oemar. (2001). Kurikulum dan Pembelajaran. Jakarta: PT. Bumi Aksara.

Mapilindo. Rahmayanti. Gulyanto, B. (2021). Efektifitas Penggunaan Modul Terhadap Hasil Belajar Siswa pada Mata Pelajaran Matematika kelas X Program IPS SMA Negeri 1 Kisaran. JEMS: Jurnal Edukasi Matematika dan Sains. Volume 9, nomor 2.

Mustaji. (2008). Pembelajaran Mandiri. Surabaya: Unesa FIP.

Ramadhani, Rahma., Amudi, A. (2020). Efektifitas Penggunaan Modul Matematika Dasar Pada Materi Bilangan Terhadap Hasil Belajar. AKSIOMA: Jurnal Program Studi Pendidikan Matematika, Volume 9, No.1.

Soedjadi, R. (2000). Kiat Pendidikan Matematika di Indonesia. Departemen Pendidikan Nasional.

Sudjana, Nana dan Rivai, Ahmad. (2007). Media Pengajaran. Bandung: Sinar Baru Algesindo. Syaodih S, N. (2004). Kurikulum dan Pembelajaran Kompetensi. Bandung: Kesuma Karya.

Utomo, Tjipto. (1991). Peningkatan dan Pengembangan Pendidikan. Jakarta: Gramedia Pustaka Utama.

Vembriarto, St. (1975). Pengantar Pengajaran Modul. Yogyakarta: Yayasan Pendidikan Paramita

Wijaya, cece, dkk. (1988). Upaya Pembaharuan Pendidikan dan Pengajaran. Bandung: Remadja Karya.

Winkel. (2009). Psikologi Pengajaran. Yogyakarta: Media Abadi. 